https://doi.org/10.18485/iipe_response2covid19.2021.ch22

\title{
IMPACTS OF COVID-19 MEASURES ON WOMEN'S AND GIRLS' HUMAN RIGHTS IN TURKEY
}

\begin{abstract}
Kadriye Bakirci ${ }^{1}$
Abstract: The Presidency of Turkey has introduced measures to slow the spread of COVID-19 starting from March 2020. Even though the COVID-19 disease does not make distinctions in terms of whom to infect, surveys in Turkey demonstrate that the personal, social and economic effects of the measures against the pandemic have affected men and women differently, which is contributing to the deepening of pre-existing gender inequalities. The measures to combat the pandemic also affect different groups of women differently.

This study aims to assess the disproportionate adverse impact of COVID-19 measures on women's and girls' human rights. Herein, I draw from multiple surveys and reports to show that COVID-19 raised profound challenges with respect to women's and girls' human rights such as the right to life, well-being, equality; the right to equal access to education, essential services, justice, health services; freedom and the right to paid work; the right to equal, decent, healthy and safe working conditions; the right to the reconciliation of family and working life; the right to social insurance; and freedom of movement. As a result, it can be concluded that COVID-19 measures have placed progress towards gender equality in jeopardy for years to come.
\end{abstract}

Keywords: COVID-19, Turkey, women's human rights, children's rights, violence, multiple discrimination

\section{INTRODUCTION}

International and Turkish human rights law recognise that in the context of serious public health threats and public emergencies which threaten the life of the

\footnotetext{
${ }^{1}$ Professor, Head of Employment and Social Security Law Division, Hacettepe University Faculty of Law, 06800 Beytepe, Ankara, Turkey, kadriy_e@yahoo.co.uk, kbakirci@ hacettepe.edu.tr.
} 
nation, restrictions on some rights can be justified when they have a legal basis, are strictly necessary, based on scientific evidence and are neither arbitrary nor discriminatory in the application, of limited duration, respectful of human dignity, subject to review, and proportionate to achieve the objective (Siracusa Principles on the Limitation and Derogation Provisions in the International Covenant on Civil and Political Rights, 1984). Government strategies should address disproportionate impacts on specific populations or marginalised groups. Otherwise, restrictions can lead to negative outcomes, perpetuate inequity, and result in discrimination against women, children, older people, people with disabilities, minority groups, LGBTI people, migrants, and the poor, among others.

Turkey's Presidency has introduced measures to slow the spread of COVID-19 starting from March 2020. Even though the COVID-19 disease does not make distinctions in terms of whom to infect, the personal, social and economic effects of the measures against the pandemic do not apply equally to everyone. The surveys in Turkey demonstrate that while both women and men have been significantly negatively impacted by the crisis, they have not been affected in the same way or equally, which is contributing to the deepening of pre-existing gender inequalities. The crises also have adverse consequences for different groups of women, such as girls, younger and older, refugees, migrants, ${ }^{2}$ the poor, disabled, minority women, women in detention, women workers who are in the essential sectors, women in the informal sector, and unemployed women. Women were already in a disadvantaged position and faced challenges at home and work prior to COVID-19. COVID-19 has exacerbated these effects. Even some of the well-intended decisions, as a result of the lack of a gender-sensitive perspective, inadvertently have adverse consequences on women's human rights, which are under the protection of the UN, ILO, COE instruments (Bakirci, 2011, 2019), the Constitution of Turkey and the Turkish laws.

\section{IMPACT ON THE RIGHT TO EQUAL ACCESS TO EDUCATION}

The Turkish Presidency has temporarily closed nurseries and educational institutions to reduce the spread of COVID-19. Many schools have moved online with distance learning. However, students who have no access to the internet are left behind.

\footnotetext{
2 Turkey hosts around 3.6 million Syrians and around 400,000 refugees and asylum-seekers
} of other nationalities (Akar \& Erdogdu, 2019). 
Although school closures have affected all learners, a study implemented by the UN Women Turkey shows the increased engagement of daughters in housework reported by the majority of women (approximately 72 per cent) and of sons by about half (among those who answered) (UN Women, 2020). Therefore, girls are more prone to miss out on even distance learning.

While the fallout from schooling disruption may be limited for most girls, this may not be true for those in poor households and areas most intensively hit by COVID-19. Even when classes restart, some parents may no longer be able to afford to send their children to school ${ }^{3}$, and some teenage girls who are out of school may never return.

An analysis released by UNICEF Turkey warns that school closures, economic stress, service disruptions, pregnancy, and parental deaths due to the pandemic are putting the most vulnerable girls at increased risk of child marriage. Pandemicrelated travel restrictions and physical distancing make it difficult for girls to access the health care, social services and community support that protect them from child marriage, unwanted pregnancy and gender-based violence. Job losses and increased economic insecurity may force families to marry their daughters to ease financial burdens (UNICEF, 2021). A report by ECPAT, a network of organisations that strives to end the sexual exploitation of children, indicates that child marriage might rise in Turkey as Syrian refugees struggle during COVID-19 (ECPAT, 2020).

\section{IMPACT ON THE RIGHT TO LIFE, WELL-BEING AND GENDER EQUALITY}

The Presidency of Turkey imposed temporary curfews, such as at weekends, and the public was called on to stay in as much as possible.

Gender-based violence and all forms of violence against children have increased exponentially during COVID-19.

According to the UN Women Europe and Central Asia study, in Istanbul alone, violence against women has increased by 38 per cent since the beginning of pandemic response measures in March 2020 (UN Women Europe and Central Asia, 2020).

A report by an NGO called Socio-Political Field Research Centre shows that when asked "Have you been subjected to any violence (psychological, economic, digital, physical, sexual, emotional violence, swearing, intimidation, threats, humiliation,

\footnotetext{
${ }^{3}$ In Turkey, there are approximately 720 thousand or more working children. The rate of those who cannot continue their education is 34.3 per cent (TUIK, 2020).
} 
forced seizure of their income) in the household during quarantine?", 43 per cent of women answered "yes" (SPSM, 2020).

According to a report released by the main opposition party, 246 women were killed by men in the first ten months of 2020, and the deaths of 151 women were found "suspicious" (T24, 2020).

Another report released back in December 2020 by the Interior Ministry indicates that the perpetrators of the violence against women are mostly husbands, and the victims are mostly homemakers (Anilan, 2020).

The situation of persons with disabilities is particularly grave. According to the Report by the Socio-Political Field Research Centre, during the pandemic, violence against women with disabilities increased by 18.7 per cent. 34 per cent of women with disabilities are subjected to violence by their spouses, 16 per cent by their fathers, 13 per cent by their mothers, and 11 per cent by their children (SPSM, 2020).

The COVID-19 crisis has highlighted the precarious situation of legal and undocumented migrants, asylum seekers and refugees. The 3RP report released by the UNHCR Turkey indicates that 38 per cent of the refugee households report an increased level of stress and 13 per cent report an increased level of conflict within the household, which requires immediate protection. There are concerns that most refugee women would avoid reporting such incidents to the police because they fear deportation or increased domestic violence (UNHCR, 2020).

Although states of emergency should not function as a cover for repressive action and should not be used simply to quash human rights, we have seen the withdrawal from the Council of Europe Convention on Preventing and Combating Violence Against Women and Domestic Violence (Istanbul Convention) ${ }^{4}$ on 20 March 2021 by a Presidential Decision (No. 3718) without any parliamentary debate. The withdrawal process was completed on 1 July 2021. According to the Constitution of Turkey, withdrawing from an international treaty is a matter of legislative jurisdiction (Articles 7, 90, 104). Therefore, claims against the lawfulness of the withdrawal decision have been lodged before the Conseil d'Etat by the opposition parties, bar associations and NGOs advocating women's rights (Yazicioglu, 2021; COE, 2021). A final decision about the annulment of the Presidential Decision has not been made yet, but the Conseil d'Etat rejected to make an interim decision to halt the execution of the Presidential Decision on June 28, 2021.

\footnotetext{
${ }^{4}$ Turkey was the first country to sign (on 11 May 2011) and ratify (on 14 March 2012) the Istanbul Convention.
} 
The withdrawal prompted widespread protests from women's groups and an uproar on social media criticising that it signals a huge setback for women's rights in a country with high rates of gender-based violence and femicides (Toksabay \&Kucukgocmen, 2021).

As a result of the increase in reported assaults against women and femicide over the past year, members of the Turkish Parliament approved the establishment of a parliamentary commission to "investigate the reasons behind violence against women and to specify the measures that need to be taken" on 9 May 2021 (TBMM Meclis Haber, 2021). However, three opposition parties pulled out of the Commission in June 2021 to protest against the withdrawal from the Convention (Sozcu, 2021).

\section{IMPACT ON THE RIGHT TO EQUAL ACCESS TO ESSENTIAL SERVICES AND JUSTICE}

Due to the social distancing and confinement measures and their impact on social support and the justice system, women and children not only face a higher risk of violence during home confinement, but also have less access to social support structures such as emergency hotlines, shelters, essential housing, legal aid, police, and justice services.

According to the study implemented by the UN Women Turkey, the majority of women and men know where to seek help and support in the case of domestic violence, but one quarter (24.5 per cent of women and 25.1 per cent of men) is still not aware of how to access help. The results also reveal that region, age, and education level are influential on women's access to knowledge about support mechanisms. (UN Women, 2020).

On the other hand, women with disabilities are more exposed to multiple discriminations and violations of rights during the COVID-19 pandemic compared to normal periods and other segments of society due to their disability and femininity. According to research carried out by the Turkish Federation of the Blind, 62.7 per cent of women with disabilities could not access the support lines established by public institutions. While 27.3 per cent of women with disabilities think that they have been subjected to violations of rights, 80.8 per cent of them could not use remedial mechanisms. 71.6 per cent of women with disabilities who attempted to use remedial mechanisms stated that these mechanisms are not accessible (TFB, 2020).

\section{IMPACT ON THE RIGHT TO EQUAL ACCESS TO HEALTH SERVICES}

Since the start of the COVID-19 outbreak in Turkey, the Ministry of Health has taken various steps to provide health care for all residents, including refugees and 
regular or irregular migrants. However, several challenges arise when providing health care, including language barriers ${ }^{5}$ in accessing reliable information and access to health services, the lack of documentation, fear of deportation and stigmatisation, socioeconomic challenges, etc. (Mardin, 2017; Ozvaris et al., 2020).

While it is critical that people have access to health services and accurate information on preventing the pandemic, nearly half of the women with disabilities (45.3 per cent) could not access sufficient information about COVID-19 hospitals and health services. 70.1 per cent of women with disabilities who think that they are infected with a virus could not apply to any healthcare provider. While 43.9 per cent of women with disabilities needed psychological support during the pandemic period, 93 per cent of them could not get psychological support (TFB, 2020).

Although the impact of COVID-19 on sexual and reproductive health and rights is not yet known, according to research conducted by the UNFPA Turkey and Hacettepe University Women's Studies Centre, 26 per cent of the female health personnel participating in the research stated that sexual and reproductive health services have been interrupted during this process. The most disrupted services are listed as infertility, prenatal and postnatal care and induced abortion (UNFPA \& HUKSAM, 2020).

\section{IMPACT ON FREEDOM AND THE RIGHT TO PAID WORK AND GENDER EQUALITY IN EMPLOYMENT}

The Presidency of Turkey took some measures to protect women and workers in general. For example, paid leave was provided for civil servants aged 60 years and older, pregnant civil servants and civil servants with chronic illnesses. However, no such order exists for the private sector. Public institutions were ordered to provide alternating and flexible schedules and enforce remote working if possible. But the private sector was advised to follow this practice for jobs that did not require employees to be at the workplace (Bakirci, 2019, 2020). Therefore, many workers in the private sector and essential sectors had to continue to travel to work and attend the workplace.

\footnotetext{
${ }^{5}$ In August 2020, the Directorate General of Migration of Turkey and UNHCR launched an information campaign country-wide available in Arabic, Farsi, Turkish, and English to provide messages regarding prevention and response to sexual and gender-based violence (UNHCR, September 2020). It is particularly important for Syrian women, as only 20 per cent of Syrian women can speak Turkish.
} 
Most women employees in Turkey work in the informal sector where there is no job security and no safety net if a crisis such as COVID-19 destroys their earnings. Informal work includes many occupations most likely to be harmed by a quarantine, social distancing, and economic slowdowns, such as travel, retail, food, accommodation, seasonal agriculture, and domestic work. Women are also overrepresented in service industries that have been among the hardest hit by the response to COVID-19. In Turkey, 56 per cent of health personnel are women, meaning women are at the front lines of containing the spread of COVID-19 and may be heavily exposed to the virus through work in the health sector.

Several surveys implemented in Turkey show that women's participation in the labour market and their share among business owners was lower than men's before COVID-19. The crisis has exacerbated these inequalities. The surveys reveal considerable negative economic consequences for both women and men, in terms of reduced hours of paid work, loss of jobs, and financial worries. However, while the paid hours reduction affected men more, women lost their jobs to a higher extent (UN Women, 2020; Biamag, 2020; TEPAV, 2020).

According to a survey, conducted by the Confederation of Progressive Trade Unions of Turkey for the April 2020 period, the women's unemployment rate in Turkey is 16.3 per cent. This rate is 31.6 per cent for women with disabilities (DISK, 2020).

The COVID-19 crisis has further highlighted the precarious situation of domestic employees. A survey implemented by the Domestic Employees Union shows that 56.8 per cent of the participants said that they were laid off during the pandemic. 5.2 per cent of the domestic employees were put on unpaid leave. All in all, 91.6 per cent of the women said that they suffered an income loss in this period. 84.4 per cent said that they could not benefit from any state aid in the coronavirus period, and when they did, it was mostly temporary aid (Evid-Sen, 2020).

In the face of potentially massive lay-offs due to the effects of the pandemic, Turkey decided to implement employment protection measures. Among these measures were a ban on dismissals as well as a facilitated procedure for companies to keep their employees on unpaid leave. A new provisional article 10, which was added to the Employment Act No. 4857, prohibits the termination of employment contracts except for termination for immoral, dishonourable, or malicious conduct or other similar behaviour (Bakirci, 2019) which constitutes dismissal Code 29 in Turkey's Social Security system. However, this exemption was misused by some employers to dodge the ban on layoffs. More than 200.000 employees were dismissed by April 2021 (Hurriyet Daily News, 2021).

This is a brutal type of dismissal because an employee dismissed based on Code 29 is not entitled to severance pay, notice pay and unemployment benefits. 
Moreover, it becomes more difficult for this person to find a new job. For women employees, this cruelty is doubled. Women employees explain that the threat of dismissal has increased in their workplaces during the pandemic with this code, which covers behaviour from unexcused absenteeism to sexual crimes. Women who were fired under Code 29 explain that they were subjected to inquiries by their families about "what they got up to in their workplace", that this sometimes turns into violence; they experience serious difficulties when they are looking for a job, that they are constantly having to try and prove that they did not commit any immoral or dishonourable acts (Karaca, 2020).

In order to prevent this misuse and to protect employees, Turkey's Social Security Institution (SSI) made certain changes in relation to termination notifications of employment contracts on April 8, 20216. New codes have been defined by the SSI for immoral, dishonourable or malicious conduct or other similar behaviour in order to prevent confusion and to reveal the exact reason for the termination of the employment contract. In furtherance of the latest update, employers will have to notify SSI on how the employee acted in an immoral, dishonourable or malicious way or other similar behaviour causing the termination of the employment contract by entering the appropriate dismissal code into SSI's official online system. In this way, different termination reasons such as unexcused absenteeism and theft are made with different notification codes and possible problems are avoided.

\section{IMPACT ON THE RIGHT TO EQUAL, DECENT, HEALTHY AND SAFE WORKING CONDITIONS}

The crisis has highlighted the worsening working conditions and vulnerabilities of many essential workers. Some of the effects on the working conditions include an increase in health and safety risks, violence, discrimination, long hours of work, and reduced wages.

The research by the UNFPA Turkey and HUKSAM reveals that 48 per cent of the female health personnel participating in the study has been working in COVID-19 units and 28 per cent of them has been diagnosed with COVID-19. While 4 out of every 10 (38 per cent) stated that they work for an average of 41 hours or more

\footnotetext{
${ }^{6}$ For more information, see: SGK Genelgesi (Social Security Institution Circular) 2021/9, No.E-51592363-010.06.02-24061806, 16.04.2021, retrieved from https://www.alomaliye. com/2021/04/19/sgk-genelgesi-2021-12/. Accessed 25 May 2021.
} 
per week, it has been found that most of those who work with such an intense schedule work in COVID-19 units (UNFPA\& HUKSAM, 2020).

While 18 per cent of women with disabilities stated that they had to work on weekends and evenings as a result of the remote working practice, 15 per cent stated that their workload increased, and 15 per cent stated that the time they allocated to themselves decreased. Those who state that their salary is deducted is 10 per cent, and those who have extended their working time are 9 per cent. 44 per cent of the women with disabilities stated that the practice of working remotely causes them to have problems in socialising (TFB, 2020).

According to a report by the ILO Turkey Office and the Turkish Statistical Institute, the gender wage gap in Turkey is 15.6 per cent. The COVID-19 pandemic will increase the wage gap because sectors, such as services, retail sales and tourism, where women are predominantly employed, are the hardest hit (ILO \&TSI, 2019).

Although there are not enough surveys on the working conditions of seasonal agricultural employees, a Turkey-based NGO that works with seasonal farmers criticised the lack of precautionary measures. Employees have reportedly complained about the lack of personal protective equipment, as well as crowded transportation to the fields despite the risk of spreading COVID-19 to others (Duvar English, 2020).

An increase in mobbing, harassment and discrimination has been reported amid the ongoing pandemic by the women employees who attended the workplace.

Employees in a Turkish food packager were locked into dormitories due to COVID-19. In another factory, the factory management removed the bus service to force employees to work 12 hours a day, locked the gates of the factory so that employees would not leave early, and forced employees to work on Sundays and public holidays. The employees were not paid for overtime. Even women employees who had just given birth and were still breastfeeding were forced to work (Karaca, 2020).

The survey implemented by the Domestic Employees Union shows that 77 per cent of domestic employees was subjected to all forms of violence (namely, physical, psychological, economic and sexual) at home and work (Evid-Sen, 2020).

The problem of violence against health personnel in Turkey has remained persistent, with personnel frequently being exposed to violence and workplace assault amid the ongoing pandemic, a new report by the Union of Healthcare and Social Service Workers has revealed (Saglik-Sen, 2021).

Given the vital role that work plays in our lives, it is crucial to understand how rising levels of unemployment and inactivity have impacted mental well-being. 
The research by the UNFPA Turkey and HUKSAM shows that almost all female health professionals (94 per cent) feel anxious about the COVID-19 pandemic (UNFPA \& HUKSAM, 2020).

According to the study implemented by the UN Women Turkey, more women have experienced negative effects of COVID-19 on their mental/emotional health. 54 per cent of women and 49 per cent of men stated that they experienced problems such as stress and anxiety as a result of the outbreak (UN Women, 2020).

\section{IMPACT ON THE RIGHT TO SUBSTANTIVE EQUALITY AND RECONCILIATION OF FAMILY AND WORKING LIFE}

Day care centres and all other educational facilities were closed on March 16, 2020, in Turkey, and online education started in March 23. At the same time, the two most common non-parental arrangements for childcare-home care provided by grandparents and by paid caregivers - have become undesirable or impossible due to health concerns and curfews for individuals over 65 years of age. Women caring for one or several persons with disabilities were particularly affected by the COVID-19 crisis.

Surveys show that self-isolation measures overburden women with unpaid housework and care work as more family members spend time at home. While men also had to step in, data shows that housework and caring responsibilities more often fall on women and gendered division of household labour continues. (KESK, 2021; Illkkaracan \& Memis, 2021; Bakirci, 2020; UN Women, 2020).

According to the study implemented by the UN Women Turkey, the ratio of the increased workload of women is the highest in the categories of "cleaning and maintaining own dwelling and surroundings" and "cooking and serving meals", where 77.6 per cent and 59.9 per cent of the surveyed women stated an increase, respectively, in these household chores, compared to 47 per cent and 23.9 per cent of the surveyed men (UN Women, 2020).

39.1 per cent of the disabled women stated that their domestic workload increased during the pandemic period (TFB, 2020).

Therefore, women are caught between a domestic burden/private life and working life. Working women either reduced their hours of work or left the labour force entirely as a result of the increased housework and care responsibilities.

The study by the UN Women Turkey indicates that more women have started to work from home (UN Women, 2020).

Women took more leave of absence from work compared to men. Since the start of COVID-19, one-third of women and one-quarter of men took leave from 
their work (paid, partially paid or unpaid). Importantly, for half of the women who went on leave, the leave was unpaid (15.7 per cent), exceeding the share of men (11.2 per cent). This has implications on women's earnings and economic status within the family. Even though participants were not asked about the reasons for going on leave, it can be assumed that women's status as "secondary" earners and being expected to perform the majority of unpaid domestic and care work might be strongly influential in this regard. It is also possible that the higher share of women taking up unpaid leave is due to occupational segregation and employers' imposing unpaid leave (UN Women, 2020).

However, there are some positive signs of increased engagement of men in the household. Increased engagement of sons in housework was reported by about half of women, and other family members by two-thirds (among those who answered) (UN Women, 2020). A nationwide survey conducted in Turkey in May 2020 shows that, in a couple of households, men's unpaid work time went up nearly five-fold during the pandemic. The increase was highest for men who switched to working from home during a lockdown: they spent 50 per cent more time on domestic chores and care work than men who continued working at the workplace (UNDP, 2020).

\section{IMPACT ON THE RIGHT TO SOCIAL INSURANCE}

The rapid spread of the coronavirus raised the urgent demand to recognise COVID-19 as a work accident or occupational disease in order to ensure easier and faster access to associated benefits under the work accident or occupational disease ${ }^{7}$ insurance system (Social Security and General Health Insurance Act (SSGHIA) No.5510, Articles 13, 14), in particular for workers in the most exposed sectors such as health workers, police, food store employees, delivery workers, and others who come into regular close contact with the public. Furthermore, COVID19 is contracted while commuting to work or back home, and it should also be covered by work accident or occupational disease insurance.

However, the Social Security Institution of Turkey published a Circular classifying COVID-19 as an illness (SSGHIA, Article 15) on 7 May $2020^{8}$ rather than a work

\footnotetext{
${ }^{7}$ In its report on the application of the European Code of Social Security, the ILO Committee of Experts on the Application of Conventions and Recommendations (CEACR) considers that infection by COVID-19, if contracted as a result of work, must be considered an employment injury (ILO CEACR, 2020).

${ }^{8}$ For more information see: SGK Genelgesi (Social Security Institution Circular) 2020/12, No. 96597630-010.06.02-E.5852699, 7 May 2020, retrieved from https://www.turmob.org.tr/ mevzuat/Pdf/17715. Accessed 25 May 2021.
} 
accident or occupational disease. This declaration opened up debates on cases related to previous contagious diseases such as $\mathrm{H} 1 \mathrm{~N} 1$. There is one particular case where a truck driver lost his life due to H1N1 during a work trip from Turkey to Ukraine. It was concluded as a work accident by the Supreme Court (Court of Cassation, 21st Division, 2018/5018, 2019/2931, 15 April 2019).

After a long struggle and demand by health workers, the Ministry of Health issued a new Circular on 19 December 2020, recognising COVID-19 as an occupational disease for health workers (Ozgenc, 2020). The Circular provides occupational disease benefits for those who have suffered from the disease and for the next of kin of the staff who have died while working at hospitals.

However, the police, food store employees, delivery workers and others who are unable to telework or respect the social distance of 1.5 meters due to the nature of their job are not covered. For these workers, infection by COVID-19 could be classified as a work accident or an occupational disease depending on the circumstances, i.e., if the general conditions laid down in the SSGHIA are met. However, the request to prove the causal link between the work and the infection in order to be recognised as a work accident or occupational disease is problematic. To be considered an occupational disease, a clear connection between the disease and workplace exposure must be established. Therefore, the causal link between the work and the infection should be automatically assumed for this group of workers in order to also provide coverage for cases in which the identification of the specific causes and working methods of the infection is problematic. The proof of risk of infection should be based simply on a description of work and the extent of contact with the public.

This decision of the Social Security Institution will have legal consequences in the future and will be the subject of many lawsuits filed by the workers against the Institution, seeking a verdict in the Supreme Court.

\section{IMPACT ON FREEDOM OF MOVEMENT OF OLDER PEOPLE}

Older persons have faced higher infection and mortality rates, while at the same time being subjected to ageism/age discrimination in public discourse and isolation without access to essential services.

Emergency measures that have been put in place in Turkey have dramatically increased limitations on the freedom of movement of people over 65 because Turkey banned residents 65 years of age and older who were not employed to leave their homes with no exceptions for grocery shopping, pharmacy visits, or even taking out the garbage. On June 6th, the Presidency revised the rule to allow older people to go out between 10 am and 2 pm, Monday through Saturday. 
Although the effect of this ban on older women has not been known yet, according to a study by the UN Women Turkey, women articulated higher difficulty in accessing basic supplies and services (UN Women, 2020).

During the pandemic, 27.5 per cent of women with disabilities could not meet their self-care needs such as hair, nail, foot, mouth, partial and whole-body care and bath (TFB, 2020).

\section{IMPACT ON POSITIVE DISCRIMINATION PRINCIPLE}

COVID-19, like other infectious diseases, poses a higher risk in places of detention, such as prisons, jails, and immigration detention centres. Therefore, Turkey made amendments to the Act on the Execution of Sentences and Security Measures in April 2020 (Ceza ve Guvenlik Tedbirlerinin Infazi Hakkinda Kanun ile Bazi Kanunlarda Degisiklik Yapilmasina Dair Kanun, No. 7242, Official Journal No.31100, 15 April 2020) and released around 90,000 prisoners to ease overcrowding in jails and protect detainees. Besides women prisoners who had children aged six and younger, prisoners who required special care or were over 65 were also released. They were provided for confinement in their accommodation as a virus containment measure.

\section{COMMENT}

The scale and severity of the COVID-19 pandemic clearly rose to the level of a public health threat that could justify restrictions on certain rights. However, existing limitations on the involvement of women and their representative organisations in decision-making have resulted in a disproportionate adverse impact on women. The Turkish Presidency's response to the COVID-19 crisis is characterised by limited attention to gender issues.

The COVID-19 pandemic has deepened pre-existing inequalities in Turkey. Even the modest gains made in gender equality and women's rights over the previous decades were at risk of being reversed. Progress lost takes years to regain. Therefore, putting women's leadership and contributions at the heart of resilience and recovery is essential.

However, there is also evidence to suggest that the gender gap may be getting smaller. Surveys show that men have increased time spent on childcare and housework since the beginning of the pandemic, leading to slight shifts towards more egalitarian distributions of labour. This could lead to unpaid work being recognized and rewarded as a valuable contribution to the economy. 


\section{REFERENCES}

Akar, S., Erdogdu, M. M. (2019). Syrian Refugees in Turkey and Integration Problem Ahead. Journal of International Migration and Integration, Volume 20, pp. 925-940.

Anilan, E. (2020, December 20). Şiddet gören kadın utanıp polise gitmiyor [The abused woman is ashamed and does not go to the police]. Sabah, retrieved from https://www.sabah.com.tr/yasam/2020/12/20/siddet-goren-kadin-utanip -polise-gitmiyor. Accessed 25 May 2021.

Bakirci, K. (2020, July 3). Flash Report: Impact of COVID-19 measures on women in Turkey, retrieved from https://www.equalitylaw.eu/downloads/5171-turkeyimpacts-of-covid-19-measures-on-women-in-turkey-118-kb. Accessed 25 May 2021.

Bakirci, K. (2021). Turkey-Country Report Gender Equality, retrieved from https://www.equalitylaw.eu/downloads/5415-turkey-country-report-genderequality-2021-2-17-mb. Accessed 15 June 2021.

Bakirci, K. (2010-2011). "Gender Equality in Employment in Turkish Legislation with Comparisons to EU and International Law", Journal of Workplace Rights, 15(1-2).

Biamag (2020, March 19). 149 Bin 382 iş Yeri Geçici Süreliğine Faaliyetlerine Ara Verdi [149 thousand 382 Workplaces Suspended Their Activities Temporarily]. Biamag, retrieved from https://bianet.org/bianet/saglik/221637-149-bin-382is-yeri-gecici-sureligine-faaliyetlerine-ara-verdi, Accessed 25 May 2021.

COE. (2021, March 21). Council of Europe leaders react to Turkey's announced withdrawal from the Istanbul Convention. Press release, retrieved from https://www.coe.int/en/web/istanbul-convention/-/council-of-europe-leadersreact-to-turkey-s-announced-withdrawal-from-the-istanbul-convention; https://www.reuters.com/article/us-eu-summit-turkey-commission-idUSKBN 2BH3FH, Accessed 25 May 2021.

DISK. (2020, April 10) İşizlik ve İstihdam Raporu: Pandemi Öncesinde İşsizlikte Vahim Tablo [Employment and Unemployment Report: The Dire Picture of Unemployment Before Pandemic]. DISK, retrieved from http://disk.org.tr/ 2020/04/nisan-2020-issizlik-ve-istihdam-raporu-pandemi-oncesinde-issizliktevahim-tablo/. Accessed 25 May 2021.

Duvar English. (2020, March 12). Turkey's seasonal farmers brace for COVID-19 risk: If we don't work, we'll starve to death, retrieved from https://www. duvarenglish.com/human-rights/2020/05/12/turkeys-seasonal-farmers-bracefor-covid-19-risk-if-we-dont-work-well-starve-to-death, Accessed 25 May 2021. 
ECPAT. (2020). ECPAT Country Overview: Turkey. ECPAT International, Bangkok, retrieved from https://www.ecpat.org/wp-content/uploads/2020/07/ECPATCountry-Overview-Report-Sexual-Exploitation-of-Children-inTurkey-July-2020ENGLISH.pdf, Accessed 25 May 2021.

Evid-Sen. (2020, Nov.25). Şiddet ve Korona Dönemi Çalışma Illişkileri Raporu [Report on Violence and Labour Relations of Corona Era], retrieved from http://www.evid-sen.org/2020/11/25/evid-sen-siddet-ve-korona-donemicalisma-iliskileri-raporu/, Accessed 25 May 2021.

Hurriyet Daily News. (2021, April 8). Changes made to controversial 'Code-29' in labor law. Hurriyet Daily News, retrieved from https://www.hurriyet dailynews.com/changes-made-to-controversial-code-29-in-labor-law-163796, Accessed 25 May 2021.

ILO CEACR. (2020). Report of the CEACR of ILO concerning social security measures taken at national level in response to the COVID-19 pandemic, CEACR/XCI/2020/14 91st Session Geneva 25 November-12 December 2020, retrieved from https://rm.coe.int/ceacr-2020-report-covid-19-eng/1680a190 42, Accessed 25 May 2021.

ILO Turkey Office. (2019). A quantum leap for gender equality: For a better future of work for all report, retrieved from https://www.lo.org/wcmsp5/groups/ public/--dgreports/--dcomm/--publ/documents/publication/wcms_67 4831.pdf, Accessed 25 May 2021.

Illkkaracan, I., Memis, E. (2021). Transformations in the Gender Gaps in Paid and Unpaid Work During the COVID-19 Pandemic: Findings from Turkey. Feminist Economics, 27(1-2).

Karaca, S. (2020, September 15). The boss' dishonest weapon; code 29!. Evrensel Daily, retrieved from https://www.evrensel.net/daily/414075/the-bossdishonest-weapon-code-29, Accessed 25 May 2021.

KESK. (2021). COVID-19 Pandemisinin Kamu Emekçilerinin Çalışma Düzeni, Ücretleri ile Ev İçi iş̧ Yükü Üzerindeki Etkileri Araştırması [A Study of the Effects of COVID 19 on Working Conditions, Wages and Domestic Workload of Public Workers], retrieved from https://kesk.org.tr/2021/06/12/24468/, Accessed 14 June 2021.

Mardin, F. D. (2017). Right to Health and Access to Health Services for Syrian Refugees in Turkey, MiReKoc Policy Brief Series 2017/01, retrieved from https://mirekoc.ku.edu.tr/wp-content/uploads/2016/11/PB_Right-toHealth.pdf, Accessed 25 May 2021.

Ozgenc, M. (2020, February 19). Sağlıkçıların beklediği genelge: Covid-19 meslek hastalığı, [Circular awaited by the health workers: Covid-19 is an occupational disease], Hurriyet, retrieved from https://www.hurriyet.com.tr/gundem/ 
saglikcilarin-bekledigi-genelge-covid-19-meslek-hastaligi-41692726, Accessed 25 May 2021.

Ozvaris, S. B. \& Kayi, I.\& Mardin, D. et al. (2020). COVID-19 barriers and response strategies for refugees and undocumented migrants in Turkey. Journal of Migration and Health, Vol. 1-2, retrieved from https://www.science direct.com/science/article/pii/S266662352030012X, Accessed 25 May 2021.

Saglik-Sen. (2021, April 8). Mart Ayı Sağlıkta Şiddet Raporu [March report of the violence in the health sector], retrieved from http://www.sagliksen.org.tr/ haber/9934/saglik-sen-mart-ayi-saglikta-siddet-raporu, Accessed 25 May 2021.

SGK Genelgesi. (Social Security Institution Circular). 2021/9. No.E-51592363010.06.02-24061806, 16.04.2021, retrieved from https://www.alomaliye.com/ 2021/04/19/sgk-genelgesi-2021-12/. Accessed 25 May 2021.

SGK Genelgesi. (Social Security Institution Circular). 2020/12. No. 96597630010.06.02-E.5852699, 7.5.2020, retrieved from https://www.turmob.org.tr/ mevzuat/Pdf/17715. Accessed 25 May 2021.

Sozcu. (2021, 30 June). CHP ve IYi Parti'nin ardından HDP de komisyondan ayrıldı [After the CHP and IYI Party HDP also left the Commission]. Sozcu, retrieved from https://www.sozcu.com.tr/2021/gundem/chp-ve-iyi-partinin-ardindanhdp-de-komisyondan-ayrildi-6514744/, Accessed 22 July 2021.

SPSM. (2020). COVID-19 Karantinasından Kadının Etkilenimi Ille Kadin ve Çocuğa Yönelik Şiddete Iliş̧kin Türkiye Araştırma Raporu [Turkey Research Report on the Effects of COVID 19 Quarantine on Women and Violence against Women and Children], retrieved from https://sahamerkezi.org/wp-content/uploads/ 2020/04/kad\%C4\%B1n-covid-ek.pdf, Accessed 25 May 2021.

TBMM Meclis Haber. (2021, 9 March). TBMM Genel Kurulunda, "kadına yönelik şiddetin sebeplerinin araştırılarak alınması gereken tedbirlerin belirlenmesi" amacıyla Meclis araştırma komisyonu kurulması kabul edildi [The Turkish Grand National Assembly decided to establish a parliamentary research commission with the aim of "investigating the causes of violence against women and determining the measures to be taken"]. TBMM Meclis Haber, retrieved from https://www.tbmm.gov.tr/develop/owa/haber_portal.aciklama?p1=150663. Accessed 25 May 2021.

TEPAV. (2020). How Has COVID-19 Affected Turkey's Labor Market?, retrieved from https://www.tepav.org.tr/upload/files/1599032794 1.How_has_COVID _19_affected_Turkey___labor_market.pdf, Accessed 25 May 2021.

TFB. (2020). Violations of The Rights Of Women With Disabilities During The COVID 19 Pandemic, retrieved from https://www.stgm.org.tr/sites/default/files/2020- 
11/violations-of-the-rights-of-women-with-disabilities-during-the-covid-19.pdf, Accessed 25 May 2021.

T24. (2020, Nov 25) CHP'li Tanrıkulu'ndan '25 Kasım' raporu: 15 günde TBMM'de kadın cinayetlerinden 57 saniye söz edildi 25 November report from the deputy: Femicide in Turkey was mentioned only for 57 seconds in the Turkish Grand National Assembly in the last 15 days]. T24, retrieved from https://t24.com.tr/haber/chp-li-tanrikulu-ndan-25-kasim-raporu-15-gundetbmm-de-kadin-cinayetlerinden-57-saniye-soz-edildi,916985. Accessed 25 May 2021.

Toksabay, E., \& Kucukgocmen, A. (2021, 1 July). Women protest as Turkey quits violence-on-women treaty. Reuters, retrieved from https://www.reuters.com /world/middle-east/turkey-formally-quits-treaty-prevent-violence-againstwomen-2021-07-01/, Accessed 22 July 2021.

TUIK. (2020, March 31). Çocuk İşgücü Anketi Sonuçları, 2019 [Child Labour Survey 2019], retrieved from https://data.tuik.gov.tr/Bulten/Index?p=Child-LabourForce-Survey-2019-33807. Accessed 25 May 2021.

UNICEF Turkey. (2021). 10 million additional girls at risk of child marriage due to COVID-19, retrieved from https://www.unicef.org/turkey/en/press-releases/10million-additional-girls-risk-child-marriage-due-covid-19. Accessed 25 May 2021.

UN Women Turkey. (2020). The economic and social impact of COVID-19 on women and men Rapid Gender Assessment of COVID-19 implications in Turkey, retrieved from https://www2.unwomen.org/-/media/field\%20office\%20eca/ attachments/publications/2020/06/rapid\%20gender\%20assessment\%20report \%20turkey.pdf?la=en\&vs=438. Accessed 25 May 2021.

UN Women Europe and Central Asia. (2020). Amid COVID-19 lockdown in Turkey, UN Women runs campaign to curb violence against women and promote gender equality at home, retrieved from https://eca.unwomen.org/en/ news/stories/2020/5/amid-covid19-lockdown-in-turkey-un-women-runscampaign-to-curb-vaw-and-promote-gender-equality. Accessed 25 May 2021.

UNHCR (2020, Feb.). Turkey: 3RP Country Chapter-2020/2021 - EN, retrieved from 3RP Turkey Country Chapter 20202021 EN v4 optimized (2).pdf. Accessed 25 May 2021.

UNHCR. (2020, September). Turkey Fact Sheet, retrieved from https://relief web.int/sites/reliefweb.int/files/resources/UNHCR\%20Turkey\%20General\%20F act\%20Sheet\%20September\%202020.pdf, Accessed 25 May 2021.

UNFPA Turkey \& HUKSAM. (2020). COVID-19 Pandemisi Sürecinde Kadın Sağlık Çalışanlarının Özelleşmiş Ihtiyaçlarinin Değerlendirilmesi Araştırması [A Study 
on the Special Needs of Female Health Workers during the COVID-19]. retrieved from https://turkey.unfpa.org/sites/default/files/pub-pdf/kadinsaglikcalisanlari covid19-sonrapor-son_0.pdf, Accessed 25 May 2021.

UNDP. (2020). Research Brief: Gender Gaps in the Care Economy during the COVID19 Pandemic in Turkey, retrieved from https://www.tr.undp.org/content/ turkey/en/home/library/corporatereports/COVID-gender-survey-report.html, Accessed 25 May 2021.

Yazicioglu, Y. (2021, March 29). Women launch legal struggle for Istanbul Convention. VOA Turkey, retrieved from https://www.amerikaninsesi.com/ a/kadinlar-istanbul-sozlemesi-icin-hukuk-mudahalesi-baslatti/5832762.html, Accessed 25 May 2021. 